\title{
Pengelompokan Kelelawar Pemakan Buah dan Nektar Berdasarkan Karakteristik Jenis Pakan Polen di Kebun Raya Bogor, Indonesia
}

\author{
Sri Soegiharto ${ }^{1)}$, Agus P. Kartono ${ }^{2)}$, \& Ibnu Maryanto ${ }^{3)}$ \\ ${ }^{1}$ Peneliti Balai Besar Dipterocarpa Samarinda, Email: srisoegiharto@gmail.com \\ ${ }^{2}$ Staf Pengajar Mayor KVT IPB Bogor, Email: apkartono@yahoo.co.id \\ ${ }^{3}$ Peneliti Zoologi LIPI Cibinong, Email: ibnu_mar@yahoo.com
}

\begin{abstract}
The Grouping of Fruit Bats Based on Pollend Type Characterized as Food Resources in Bogor Botanical Garden, Indonesia. A study was conducted to identify pollen consummed by fruits bat in Bogor Botanical Garden from March 2008 to June 2009. The types of crown of the flower, pollen and pollen size which chosen by fruit bats were analysed by using high detrended canonical correspondent. The result indicated that there are three major groups of bats based on the similarities of food type or flower resources consumed by fruit bats. The groups were (1) males of Macroglossus sobrinus and the females of Eonycteris spelaea, (2) Cynopterus brachyotis and the females of $C$. minutus, and (3) males and females of $C$. titthaheileus, females of $C$. brachyotis and Macroglossus sobrinus, males of $C$. sphinx and $C$. minutus, and females of $C$. sphinx.
\end{abstract}

Key words: Megachiroptera, pollend, seed distribution,

\section{PENDAHULUAN}

Kelelawar memiliki peran ekologis yang penting sebagai pemencar biji buahbuahan seperti sawo, jambu air, jambu biji, duwet dan cendana (Dumont et al. 2004); serta penyerbuk bunga dari tanaman bernilai ekonomis tinggi seperti petai, durian, bakau, kapuk randu dan mangga. Kelelawar Megachiroptera, terutama pada genus Pteropus sangat berperan penting dalam penyerbukan dan pemencaran biji (Pierson \& Rainey 1992; Wiles \& Fujita 1992). Spesies anggota pada genus ini mengunjungi kurang lebih 26 spesies tumbuhan berbunga dan 64 tumbuhan buah, serta membantu penyerbukan lebih dari 31 genus dan 14 famili Angiosperma (Marshall 1985).

Keanekaragaman jenis tumbuhan di Kebun Raya Bogor tergolong tinggi. Jumlah koleksi terakhir sampai Januari 2006 terdiri atas 222 famili, 1.257 genera, 3.423 jenis dan lebih dari 13.684 spesimen tanaman hidup (Subarna 2006). Kelelawar Cynopterus sp. di Kebun Raya Bogor memakan 48 jenis tumbuhan yang sebagian besar $(74,38 \%)$ merupakan tumbuhan hutan dan bagian yang dimakan adalah buah dan daun (Suyanto 2001). Meskipun demikian, kelelawar merupakan salah satu hewan yang masih kurang 
diperhatikan dalam upaya konservasinya. Hal ini dikarenakan lemahnya pengetahuan masyarakat akan arti penting kelelawar dalam rangkaian mata rantai ekologi.

Dari uraian tersebut penelitian ini dilakukan dengan beberapa tujuan, yaitu 1) mengidentifikasi jenis-jenis tumbuhan pakan yang dimakan kelelawar, 2) menentukan penge-lompokan masingmasing jenis kelelawar jantan dan betina terhadap faktor tumbuhan pakan (tipe mahkota bunga, tipe polen dan ukuran polen) dalam pemilihan jenis tumbuhan pakan kelelawar. Hasil penelitian diharapkan dapat memberikan manfaat antara lain: 1) mengetahui karakteristik jenis tumbuhan pakan kelelawar dalam upaya mendukung konservasi di daerah perkotaan, 2) memberikan informasi kepada masyarakat akan perlunya upaya konservasi terhadap jenis-jenis kelelawar di daerah perkotaan.

\section{BAHAN DAN CARA KERJA}

Penelitian dilakukan di Kebun Raya Bogor (KRB) selama 16 bulan, mulai Maret 2008 hingga Juni 2009. Pengambilan sampel kelelawar dilakukan di KRB setiap dua minggu sekali sebanyak 2 ekor setiap spesies tertangkap di 13 lokasi titik penangkapan.

Untuk penempatan misnet (jaring kabut) ditempatkan menggunakan teknik purposive sampling sedangkan pengambilan sampel kelelawar menggunakan teknik random sampling. Jaring kabut yang dipasang pada waktu senja hari pada pukul 17.00-18.00 WIB dan pagi hari pada pukul 06.00-08.00 WIB dilakukan pengecekan jaring kabut dan pengam- bilan kelelawar. Pengambilan sampel kelelawar dilakukan selama kurun waktu 16 bulan, untuk tiap bulannya dilakukan dengan selang waktu 2 minggu sekali. Jumlah sampel kelelawar yang diambil tiap 2 minggu sekali berjumlah 2 ekor untuk tiap masing-masing jenis kelelawar.

Pengambilan kelelawar dipilih untuk tiap jenis yang mewakili spesiesnya masing-masing jantan dan betina. Spesies kelelawar yang diambil adalah Cynopterus minutus, C. brachyotis, C. sphinx, C. titthaecheilus, Macroglossus sobrinus, Rousettus amplexicaudatus dan Eonycteris spelaea.

Proses analisis polen dilakukan secara hati-hati, mengingat ukuran polen yang sangat kecil $10 \mu \mathrm{m}-200 \mu \mathrm{m}$ menyebabkan polen mudah berpindah dari tempat satu ketempat yang lain.

Pengambilan sampel polen didapat dari isi pencernaan kelelawar. Hasil dari isi pencernaan kemudian dicampur kedalam alkohol $70 \%$ dan dimasukkan ke dalam tabung reaksi selanjutnya dilakukan pemusingan dengan putaran 2000 rpm selama 30 menit, langkah selanjutnya dilakukan pembuangan cairan alkohol yang digunakan dan diganti dengan alkohol yang baru. Langkah tersebut dilakukan pengulangan sebanyak tiga kali. Endapan yang dihasilkan dari proses pemusingan diletakkan pada gelas objek sebanyak satu tetes kemudian ditetesi dengan gliserol dan ditutup dengan cover glass dengan bagian tepinya direkatkan menggunakan kuteks kuku. Penggunaan gliserol pada analisis ini diperuntukkan sebagai bahan pengawet (Yulianto 1992).

Pengamatan dilakukan dengan menggunakan mikroskop cahaya dengan 
perbesaran 10, 45 dan 100 kali. Pendataan dilakukan dengan mencatat dan menggambar jenis polen yang ditemukan dalam object glass. Langkah selanjutnya dihitung jumlah polen yang ditemukan. Polen yang ditemukan di dalam perut kemudian diidentifikasi sampai tingkat famili dan genus menurut kunci determinasi Erdmant (1952), Nayar (1999) dan Paldat (2005).

Data yang dihasilkan ditranformasi sesuai dengan sebaran data. Pada penelitian ini data yang dihasilkan dalam bentuk persentase, sehingga bentuk transformasi yang digunakan adalah transformasi arcsin (Syahid 2009).

Pengelompokan kelelawar pemakan buah dan nektar berdasarkan karakteristik jenis pakan dianalisis menggunakan pendekatan analisis multivariate hiper Detrend Canonical Corespondence Analysis (hDCCA) menurut ter Braak \& Smilauer (1998). Penggunaan metode $h$ DCCA ini bertujuan untuk menentukan kedekatan pengelompokan dalam bentuk grafik serta mengungkap informasi maksimum dari suatu matriks data dengan faktor lingkungan secara bersamaan. Matriks data yang digunakan terdiri atas jenis kelelawar jenis tumbuhan yang teridentifikasi sebagai sampel dan 3 parameter lingkungan yaitu tipe mahkota bunga, tipe polen dan ukuran polen. Bentuk mahkota bunga terbagi kedalam 8 tipe, yaitu tabung, bintang, disk, kupu, lonceng, mangkuk, kedok, dan bulir.

Menurut Tjitrosoepomo (2007) bentuk mahkota bunga dibagi kedalam beberapa bentuk (1) bintang (rotatus atau stellatus), (2) tabung (tubulosus), (3) kupu-kupu (papilio-naceus), (4) mangkuk (urceolatus), (5) berto-peng/ berkedok (personatus), (6) lonceng (campanulatus), (7) disk, dan (8) bulir.

Untuk tipe polen dibedakan berdasarkan kelas permukaannya yang ditentukan melalui perbandingan sumbu polar $(\mathrm{P})$ dengan total lebar polen $(\mathrm{E})$ menurut Erdtman (1943). Berdasarkan rasio $\mathrm{P} / \mathrm{E}$ maka tipe polen dapat diklasifikasikan ke dalam: (a) peroblate, rasio $\mathrm{P} / \mathrm{E}$ kurang dari 4/8, (b) oblate, rasio $\mathrm{P} / \mathrm{E}=4 / 8-6 / 8$, (c) sub-spheroidal, rasio $\mathrm{P} / \mathrm{E}=6 / 8-8 / 6$, (d) prolate, rasio $\mathrm{P} /$ $\mathrm{E}=8 / 6-8 / 4$, dan (e) perprolate, rasio $\mathrm{P} /$ $\mathrm{E}>8 / 4$. Tipe polen subspheroidal selanjutnya dapat dibagi lagi ke dalam: (a) suboblate, rasio $\mathrm{P} / \mathrm{E}=6 / 8-7 / 8$, (b) oblate spheroidal, rasio $\mathrm{P} / \mathrm{E}=7 / 8-8 / 8$, (c) prolate spheroidal, rasio $\mathrm{P} / \mathrm{E}=8 / 8-8 / 7$, dan (d) sub-prolate, rasio $\mathrm{P} / \mathrm{E}=8 / 7-8 / 6$ (Erdmant 1952).

Ukuran polen dibagi menurut Erdtman (1943) yaitu sangat kecil/ perminute $(<10 \mu \mathrm{m})$, kecil/minute $(10$ $25 \mu \mathrm{m})$, sedang/mediae $(25-50 \mu \mathrm{m})$, besar/magnae $(50-100 \mu \mathrm{m})$, sangat besar/permagnae $(100-200 \mu \mathrm{m})$, dan raksasa/giganteae $(>200 \mu \mathrm{m})$. Analisis pengaruh karakteristik bentuk bunga, tipe dan ukuran polen dengan $h \mathrm{CCA}$ menggunakan software Canoco for Windows 4.5 (Leps \& Smilauer 1999).

\section{HASIL}

Hasil analisis polen dapat diketahui jumlah persentase polen masing-masing spesies kelelawar. Penyajian data dilakukan dalam 3 bentuk, yaitu (1) persentase pakan kelelawar dengan jenis 
mahkota bunga disajikan pada Tabel 1, (2) persentase pakan kelelawar dengan tipe polen disajikan pada Tabel 2, dan (3) persentase pakan kelelawar dengan ukuran polen disajikan pada Tabel 3.

Hasil analisis pengelompokkan jenis kelelawar jantan dan betina berdasarkan tipe mahkota, tipe polen, dan ukuran polen menggunakan hDCCA terlihat pada Gambar 1 variasi data spesies yang dapat diterangkan adalah untuk axis $1=0,146$, dengan eigenvalue $=0,753$; axis $2=$ 0,177 , dengan eigenvalue $=0,162$. Axis 1 pada analisis $h$ DCCA menjelaskan kedekatan masing-masing kelompok kelelawar pada pemilihan tipe mahkota, tipe dan ukuran polen. Axis 2 menjelaskan hubungan kedekatan anggota spesies dalam satu kelompok atau antar kelompok dalam nilai axis 1 yang sama.

Hasil analisis memperlihatkan (Gambar 1) bahwa jenis Macroglossus sobrinus jantan dan Eonycteris spelaea betina membentuk kelompok pertama yang memiliki kesamaan pemilihan tipe pakan. Kelompok kedua terdiri dari Cynopterus brachyotis jantan dan $C$. minutus betina. Kelompok ketiga terdiri dari $C$. titthaecheilus betina dan $C$. titthaecheilus jantan, $C$. brachyotis betina, M.sobrinus betina, C. sphinx jantan, C. minutus jantan, C. sphinx betina.

Kelompok pertama terbagi menjadi dua sub kelompok, sub kelompok A terdiri dari jenis Macroglossus sobrinus jantan dan sub kelompok B terdiri dari jenis Eonycteris spelaea betina. Kelompok ketiga terbagi menjadi tiga sub kelompok yaitu sub kelompok C, sub kelompok D dan subkelompok E. Pada sub kelompok C terdiri dari jenis $C$. titthaecheilus, jantan dan C. titthaecheilus, betina, sub kelompok D terdiri dari jenis $C$.

Tabel 1. Persentase mahkota bunga yang ditemukan pada masing-masing jenis kelelawar.

\begin{tabular}{|c|c|c|c|c|c|c|c|c|c|}
\hline \multirow{2}{*}{$\begin{array}{l}\text { Jenis } \\
\text { Kele- } \\
\text { lawar }\end{array}$} & $\begin{array}{c}\text { Mahkota } \\
\text { Bunga }\end{array}$ & Tabung & Bintang & Disk & Kupu & Lonceng & Mangkuk & Kedok & Bulir \\
\hline & Sex & & & & & & & & \\
\hline \multirow[t]{2}{*}{$\overline{\mathrm{CM}}$} & $\hat{0}$ & & & 30,7 & 7,26 & 7,26 & & 11,03 & 43,74 \\
\hline & q & & 1,86 & 27,77 & & 9,09 & & & 61,28 \\
\hline \multirow[t]{2}{*}{$\mathrm{CB}$} & o & & & 68,88 & & & 7,40 & 9,55 & 14,18 \\
\hline & q & & 4,15 & 52,95 & & & & 9,06 & 33,84 \\
\hline \multirow[t]{2}{*}{$\mathrm{CS}$} & $\hat{0}$ & & & 44,08 & 14,48 & & & & 41,44 \\
\hline & o & & & 29,58 & & 12,66 & 7,23 & & 50,53 \\
\hline \multirow[t]{2}{*}{$\mathrm{CT}$} & $\sigma^{\lambda}$ & & 4,95 & 42,11 & 25,24 & & & 18,1 & 9,61 \\
\hline & q & & & 68,39 & 12,54 & & & & 19,08 \\
\hline \multirow[t]{2}{*}{ M } & $\hat{0}$ & 18,40 & 21,47 & 48,74 & & & & & 11,39 \\
\hline & q & & & 57,03 & & & & & 42,97 \\
\hline \multirow[t]{2}{*}{$\mathrm{R}$} & $\hat{0}$ & & & & & & & & \\
\hline & 우 & & & & & & & & 100 \\
\hline \multirow[t]{2}{*}{ E } & $\sigma^{\lambda}$ & & & & & & & 100 & \\
\hline & o & & & 85,05 & & 2,97 & & & 11,99 \\
\hline
\end{tabular}

Keterangan : $\mathrm{CM}=$ Cynopterus minutus, $\mathrm{CB}=$ C. brachyotis, $\mathrm{CS}=$ C. sphinx, $\mathrm{CT}=C$. titthaecheilus, $\mathrm{R}=$ Rousettus amplexicaudatus, $\mathrm{M}=$ Macroglossus sobrinus, $\mathrm{E}=$ Eonycteris spelaea . 
Pengelompokan Kelelawar Pemakan buah dan nektar

Tabel 2. Persentase tipe polen yang ditemukan pada masing-masing jenis kelelawar

\begin{tabular}{|c|c|c|c|c|c|c|c|c|}
\hline \multirow{2}{*}{$\begin{array}{l}\text { Jenis } \\
\text { Kele- } \\
\text { lawar }\end{array}$} & $\begin{array}{l}\text { Tipe } \\
\text { Polen }\end{array}$ & Peroblate & Oblate & $\begin{array}{l}\text { Sub- } \\
\text { Oblate }\end{array}$ & $\begin{array}{r}\text { Oblate } \\
\text { Spheroidal }\end{array}$ & $\begin{array}{r}\text { Prolate } \\
\text { Spheroidal }\end{array}$ & Prolate & $\begin{array}{r}\text { Per- } \\
\text { Prolate }\end{array}$ \\
\hline & Sex & & & & & & & \\
\hline \multirow[t]{2}{*}{$\mathrm{CM}$} & $\hat{\sigma}$ & & 36,31 & 56,42 & 7,26 & & & \\
\hline & 우 & & 14,94 & 6,5 & 76,69 & & & 1,86 \\
\hline \multirow[t]{2}{*}{ CB } & $\hat{\sigma}$ & 11,93 & & 41,9 & 39,45 & & 6,72 & \\
\hline & 우 & & 64,72 & & 35,28 & & & \\
\hline \multirow[t]{2}{*}{$\mathrm{CS}$} & $\sigma^{\lambda}$ & & 14,48 & 85,52 & & & & \\
\hline & 우 & 7,23 & & 7,23 & 74,92 & & 10,61 & \\
\hline \multirow[t]{2}{*}{ CT } & $\sigma^{\lambda}$ & & 43,34 & & 37,59 & 14,13 & 4,95 & \\
\hline & 우 & & 42,67 & 15,16 & 42,17 & & & \\
\hline \multirow[t]{2}{*}{ M } & $\widehat{\sigma}$ & & 29,66 & 35,65 & 23,01 & 11,69 & & \\
\hline & q & & & & 57,03 & & 42,97 & \\
\hline \multirow[t]{2}{*}{$\mathrm{R}$} & $\widehat{\sigma}$ & & & & & & & \\
\hline & 우 & & & & 100 & & & \\
\hline \multirow[t]{2}{*}{$\mathrm{E}$} & $\sigma^{\lambda}$ & & & 100 & & & & \\
\hline & q & & 34,21 & 5,01 & 14,95 & 39,85 & 5,97 & \\
\hline
\end{tabular}

Keterangan : $C M=$ Cynopterus minutus,$C B=C$. brachyotis, $C S=C$. sphinx, $C T=C$. titthaecheilus, $R=$ Rousettus amplexicaudatus, $M=$ Macroglossus sobrinus, $E=$ Eonycteris spelaea,

Tabel 3. Persentase ukuran polen yang ditemukan pada masing-masing jenis kelelawar

\begin{tabular}{|c|c|c|c|c|}
\hline \multirow[t]{2}{*}{ Kele-lawar } & Ukuran Polen & Gigantea & Permagnae & Magnae \\
\hline & Sex & & & \\
\hline \multirow[t]{2}{*}{$\mathrm{CM}$} & $\sigma^{\pi}$ & 40,77 & 43,58 & 15,65 \\
\hline & q & 46,29 & 53,71 & \\
\hline \multirow[t]{2}{*}{$\mathrm{CB}$} & $0^{\lambda}$ & 52,24 & 44,2 & 3,57 \\
\hline & ox & 35,8 & 64,2 & \\
\hline \multirow[t]{2}{*}{ CS } & $0^{\lambda}$ & 14,48 & 85,52 & \\
\hline & q & 13,92 & 86,08 & \\
\hline \multirow[t]{2}{*}{ CT } & $0^{\lambda}$ & 44,04 & 41,83 & 14,13 \\
\hline & 우 & 25,74 & 61,78 & 12,47 \\
\hline \multirow[t]{2}{*}{ M } & $\hat{\sigma}$ & 61,04 & 20,56 & 18,4 \\
\hline & 우 & & 100 & \\
\hline \multirow[t]{2}{*}{$\mathrm{R}$} & $\sigma^{\lambda}$ & & & \\
\hline & 우 & & 100 & \\
\hline \multirow[t]{2}{*}{ E } & $0^{\lambda}$ & 100 & & \\
\hline & 우 & 92,87 & 7,13 & \\
\hline
\end{tabular}

Keterangan : $C M=$ Cynopterus minutus,$C B=C$. brachyotis, $C S=C$. sphinx, $C T=C$. titthaecheilus, $R=$ Rousettus amplexicaudatus, $M=$ Macroglossus sobrinus, $E=$ Eonycteris spelaea, 


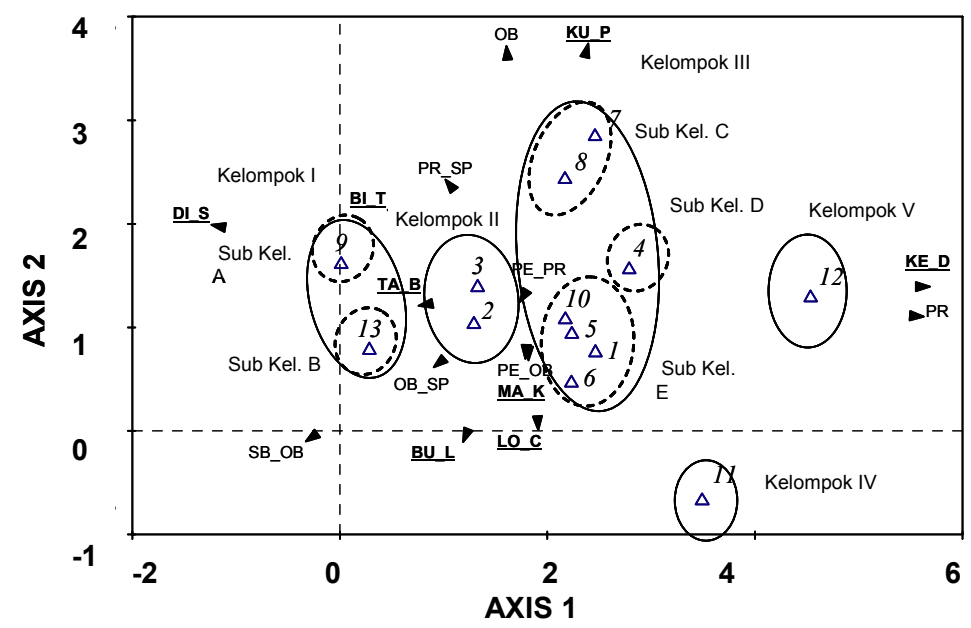

Gambar 1. Pengelompokkan kelelawar berdasarkan karakteristik mahkota bunga, tipe polen.

Keterangan : $1 .=C$. minutus jantan, $2=C$. minutus betina, $3=C$. brachyotis jantan, $4=C$. bracyotis betina, $5=C$. sphinx jantan, $6=C$. sphinx betina, $7=C$. titthaecheilus, jantan, $8=C$. titthaecheilus, betina, $9=M$. sobrinus jantan, $10=$ M. sobrinus betina, $11=R$. amplexicaudatus betina, $12=$ E. spelaea jantan, $13=E$. spelaea betina. $\mathrm{SB} \_\mathrm{OB}=$ Sub Oblate, $\mathrm{OB}=$ Oblate, $\mathrm{PR} \_\mathrm{SP}=$ Prolate Speroidal, $\mathrm{PE} \_\mathrm{PR}=$ Perprolate, $\mathrm{PR}=$ Prolate, $P E \_O B=$ Peroblate, $\mathrm{OB} \_\mathrm{SP}=$ Oblate spheroidal. TA_B $=-$ Tabung, BI_T $=$ Bintang, DI_S $=$ Disk, KU_P $=\overline{\text { Kupu}}$ $k u p u, \mathrm{LO} \_\mathrm{C}=$ Lonceng, MA_K=Mangkuk,KE_D $=$ Kedok, BU_L=Bulat.

brachyotis betina, sub kelompok E terdiri dari jenis M. sobrinus betina, C. sphinx jantan, C. minutus jantan, C. sphinx betina. Kelompok keempat ditempati jenis $R$. amplexicaudatus betina, dan pada kelompok kelima ditempati oleh jenis E. spelaea jantan.

Hasil analisis pengelompokkan jenis kelelawar jantan dan betina berdasarkan tipe mahkota, tipe polen, dan ukuran polen menggunakan hDCCA terlihat pada Gambar 1. variasi data spesies yang dapat diterangkan adalah untuk axis $1=$ 0,146 , dengan eigenvalue $=0,753$; axis $2=0,177$, dengan eigenvalue $=0,162$. Axis 1 pada analisis $h$ DCCA menjelaskan kedekatan masing-masing kelompok kelelawar pada pemilihan tipe mahkota, tipe dan ukuran polen. Axis 2 menjelaskan hubungan kedekatan anggota spesies dalam satu kelompok atau antar kelompok dalam nilai axis 1 yang sama. Macroglossus sobrinus jantan dan Eonycteris spelaea betina membentuk kelompok pertama yang memiliki kesamaan pemilihan tipe pakan. Kelompok kedua terdiri dari Cynopterus brachyotis jantan dan $C$. minutus betina. Kelompok ketiga terdiri dari $C$. titthaecheilus betina dan $C$. titthaecheilus jantan, C. brachyotis betina, Macroglossus sobrinus betina, $C$. sphinx jantan, $C$. minutus jantan, $C$. sphinx betina.

Kelompok pertama terbagi menjadi dua sub kelompok, sub kelompokA terdiri dari jenis Macroglossus sobrinus jantan dan sub kelompok B terdiri dari jenis 
Eonycteris spelaea betina. Kelompok ketiga terbagi menjadi tiga subkelompok yaitu sub kelompok C, subkelompok D dan subkelompok E. Pada sub kelompok C terdiri dari jenis C. titthaecheilus jantan dan C. titthaecheilus, betina, sub kelompok D terdiri dari jenis $C$. brachyotis betina, sub kelompok E terdiri dari jenis Macroglossus sobrinus betina, C. sphinx jantan, C. minutus jantan, $C$. sphinx betina. Kelompok keempat ditempati jenis $R$. amplexicaudatus betina, dan pada kelompok kelima ditempati oleh jenis E. spelaea jantan.

Pengelompokan jenis kelelawar didasarkan oleh karakteristik mahkota bunga, tipe dan ukuran polen (Gambar 1 dan Gambar 2). Kelompok pertama dipengaruhi oleh mahkota bunga disk, bintang, tabung dan tipe polen sub oblate, oblate spheroidal dan prolate spheroidal. Jenis $M$. sobrinus jantan dipengaruhi ukuran polen magnae membentuk sub kelompok A, sedangkan jenis E. spelaea betina dipengaruhi oleh ukuran polen magnae dan giganteae membentuk sub kelompok B. Kelompok kedua dipengaruhi oleh mahkota mangkuk, lonceng, bulat dan tipe polen peroblate dan perprolate. Kelompok kedua ini dipengaruhi oleh ukuran polen permagnae. Kelompok ketiga dibagi menjadi subkelompok C, D dan sub kelompok E. Pada subkelompok C dipengaruhi oleh bentuk mahkota kupukupu dan tipe polen oblate dan ukuran polen giganteae.

Sub kelompok D dan E dipengaruhi oleh bentuk mahkota mangkuk, lonceng dan tipe polen peroblate dan perprolate. C. brachyotis betina dipengaruhi oleh ukuran polen magnae membentuk sub kelompok C. Untuk sub kelompok E mengindikasikan kurang dipengaruhi oleh ukuran polen permagnae. Kelompok keempat dikelompokkan oleh pengaruh bentuk mahkota, tipe dan ukuran polen. Kelompok kelima dipengaruhi oleh mahkota kedok, tipe polen prolate serta ukuran polen giganteae.

Pada Gambar 3. akan tampak jenisjenis tumbuhan pakan yang mempengaruhi pengelompokkan kelelawar. Pada kelompok pertama jenis yang mempengaruhi adalah jenis Anacardium sp., Adenanthera sp., Apocynaceae sp.1., Paceae sp.1, Syzygium sp.1. Kelompok kedua jenis yang mempengaruhi adalah Anacardium sp.3., Annona sp., Ceiba sp.3, Ceiba sp.1, Acanthaceae sp.1, Pinaceae sp.1, Begoniaceae sp.1, Duabanga sp., Eugenia sp. Pada kelompok ketiga yang terbagi kedalam 2 sub kelompok, masing-masing sub kelompok memiliki keterkaitan jenis yang berbeda. Sub kelompok A jenis tumbuhan yang mempengaruhi adalah Hisbiscus sp. Sub kelompk B jenis tumbuhan yang mempengaruhi adalah [Orchidaceae] sp.2, Acacia sp., [Convolvulaceae] sp.1, Cyathea sp., Salacia sp., [Convolvulaceae] sp.2, Cyperus sp., Croton sp., [Acanthaceae] sp.1, [Pinaceae] sp.1, [Begoniaceae] sp.1. Kelompok keempat tidak ada tumbuhan yang mempengaruhi kuat. Kelompok kelima dipengaruhi oleh tumbuhan jenis [Orchidaceae] sp.3.

\section{PEMBAHASAN}

Pada pengelompokan kelelawar berdasarkan karakteristik polen tumbuhan pakan dapat dibedakan 


\section{Soegiharto, Kartono, \& Maryanto}

A)

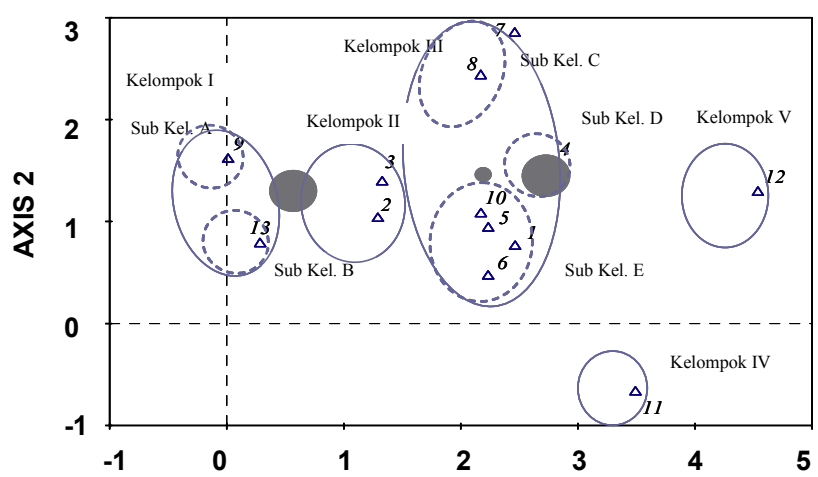

AXIS 1

B)

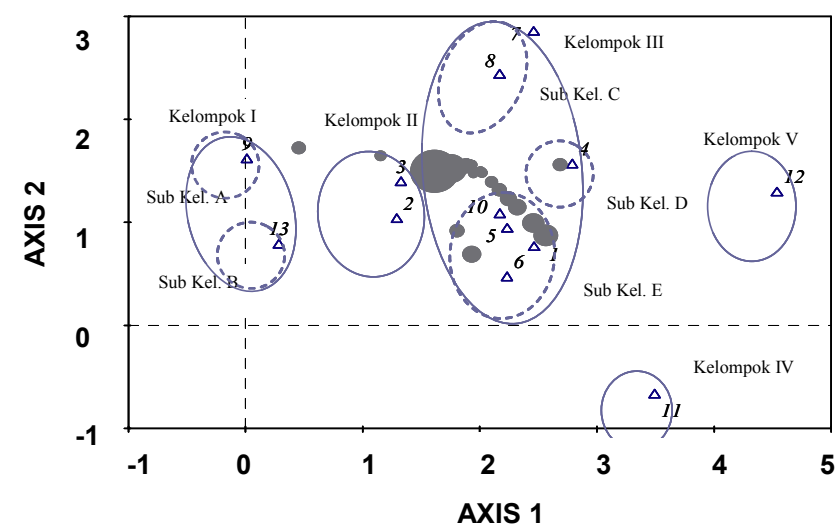

C)

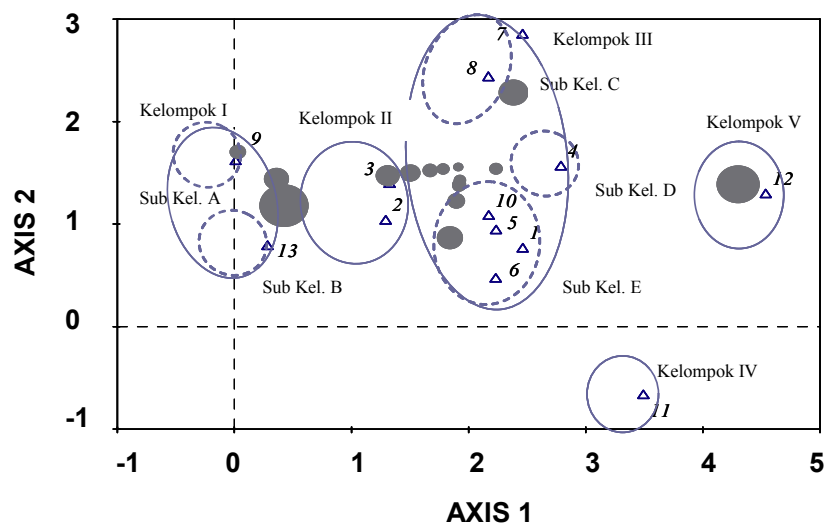

Gambar 2. Karakterıstık ukuran polen yang mempengaruhı pengelompokan lala1. a. ukuran polen magnae, b. ukuran polen permagnaee, c. ukuran polen giganteae.

Keterangan : $1 .=C$. minutus jantan, $2=C$. minutus betina, $3=C$. brachyotis jantan, $4=C$. bracyotis betina, $5=C$. sphinx jantan, $6=C$. sphinx betina, $7=C$. titthaecheilus, jantan, $8=C$. titthaecheilus, betina, $9=M$. sobrinus jantan, $10=M$. sobrinus betina, $11=R$. amplexicaudatus betina, $12=$ E. spelaea jantan, $13=$ E. spelaea betina . 


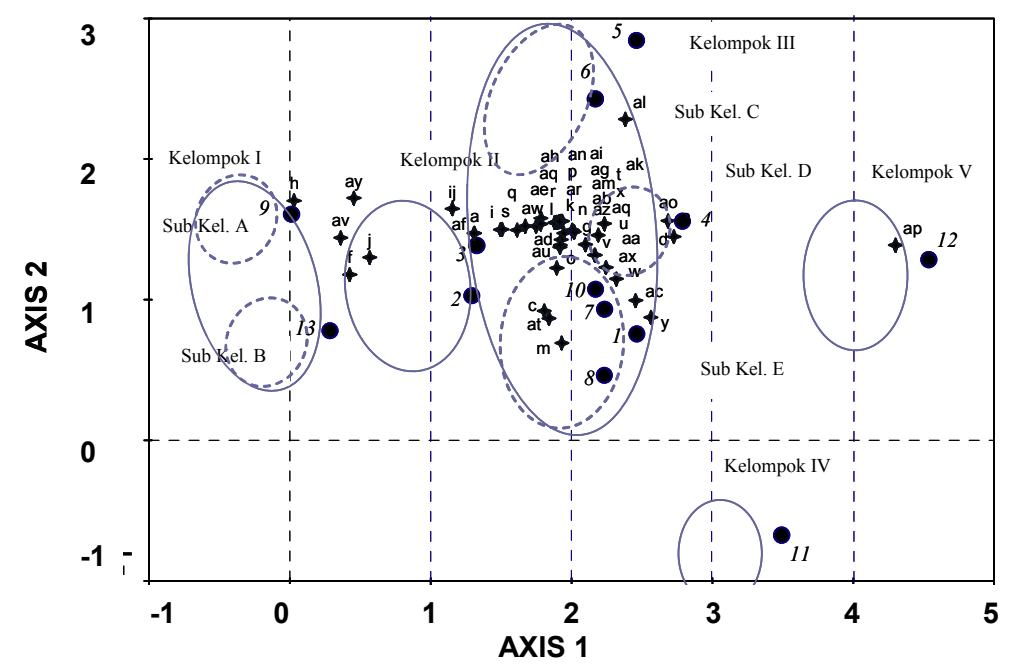

Gambar 3. Jenis tumbuhan pakan yang mempengaruhi pengelompokan lalai.

Keterangan : 1. =C. minutus jantan, $2=C$. minutus betina, $3=C$. brachyotis jantan, $4=C$. bracyotis betina, 5=C. sphinx jantan, $6=C$. sphinx betina, $7=C$. titthaecheilus, jantan, $8=C$. titthaecheilus, betina, $9=M$. sobrinus jantan, $10=M$. sobrinus betina, $11=R$. amplexicaudatus betina, $12=E$. spelaea jantan, $13=E$. spelaea betina. a=Anacardiaceae $\mathrm{sp} .3, \mathrm{c}=$ Acanthaceae sp. 1 , d=Acasia sp., e=Acasia $\mathrm{sp} .2, \mathrm{f}=$ Adenanthera $\mathrm{sp} ., \mathrm{g}=$ Alnus $\mathrm{sp} ., \mathrm{h}=$ Anacardium $\mathrm{sp} ., \mathrm{i}=$ Annona sp., $\mathrm{j}=$ Apocynaceae $\mathrm{sp} .1, \mathrm{k}=$ Baringtonia sp., $\mathrm{l}=$ Bauhinia $\mathrm{sp} ., \mathrm{m}=$ Begoniaceae $\mathrm{sp} .1, \mathrm{n}=$ Betula sp., o=Betulaceae sp. 1, p=Ceiba pentandra, q=Ceiba sp.1, r=Ceiba sp.2, s=Ceiba sp3, $\mathrm{t}=$ Celastraceae $\mathrm{sp} .1, \mathrm{u}=$ Compositae $\mathrm{sp} .1, \mathrm{v}=$ Convulvulaceae $\mathrm{sp} .1, \mathrm{w}=$ Convulvulaceae $\mathrm{sp} .2$, $\mathrm{x}=$ Crateva $\mathrm{sp} ., \mathrm{y}=$ Croton sp., $z=$ Croton $\mathrm{sp} .2$, aa=Cyathea $\mathrm{sp} ., \mathrm{ab}=$ Cyperaceae $\mathrm{sp} .2$, ac=Cyperus sp., ad=Dacrydium sp., ae=Dilleniaceae sp.1, af=Duabanga sp., ag=Durio sp., ah=Durio zibethinus, ai=Ericaceae sp.1, aj=Eugenia sp., ak=Euphorbiaceae sp.1, al=Hisbiscus sp., am=Licania sp., an=Mimosa $\mathrm{sp}$., ao=Orchidaceae $\mathrm{sp} .2$, ap=Orchidaceae $\mathrm{sp} .3$, aq=Orchidaceae sp.4, ar=Parkia sp., as=Persea sp., at=Pinaceae sp. 1, au=Pinaceae sp.2, av=Poaceae sp. 1, aw=Poaceae sp. 2, ax=Salacia sp., ay=Syzygium sp.1, az=Typhaceae sp.1

kedalam (1) fungsi kelelawar sebagai penyerbuk, (2) fungsi kelelawar sebagai penyebar biji, (3) fungsi kelelawar sebagai penyerbuk dan penyebar biji.

Fungsi kelelawar sebagai penyerbuk tumbuhan diterangkan pada pengelompokan kelelawar dengan $h$ DCCA pada kelompok 1 dan kelompok 5 (Gambar 1). Fungsi kelelawar sebagai penyerbuk tumbuhan diprediksi karena ketertarikan kelelawar oleh sumber nektar dan polen pada bunga. Jenis tumbuhan yang memiliki bunga dengan bentuk mahkota disk, bintang dan tabung diserbuki oleh jenis kelelawar E. spelaea betina, $M$. sobrinus jantan dan E. spelaea jantan. Pada jenis tumbuhan ini dimungkinkan buah yang dihasilkan setelah penyerbukan tidak disebarkan oleh jenis kelelawar. Simpulan karena hanya jenis kelelawar spesialis pemakan nektar dan polen saja yang menyukai jenis bunga ini sedangkan jenis kelelawar spesialis pemakan buah tidak menyukai jenis 
tumbuhan ini. Jenis tumbuhan sebagai penciri tersebut adalah spesies Betula sp., [Poaceae] sp.2, Adenanthera sp., [Apocynaceae] sp.1.

Tipe kelelawar dengan moncong tumpul dan cenderung sebagai penyebar biji buah dapat diterangkan pada pengelompokan kelelawar dengan $h$ DCCA seperti pada kelompok 2 (Gambar 1), walaupun jenis tersebut juga berfungsi ganda sebagai penyerbuk sebagai fungsi ke dua seperti yang terjadi pada penelitian Maryati dkk (2008). Spesies kelelawar yang tergolong dalam fungsi ini adalah $C$. minutus betina, $C$. brachyotis jantan khususnya sebagai penyebar dan penyerbuk utama tumbuhan Annona sp., [Apocynaceae] sp.1, [Anacardiaceae] sp.3, Duabanga sp. Kelelawar jenis lainnya seperti hasil analisis $h \mathrm{DCCA}$ pada kelompok 3 (Gambar 1). Spesies kelelawar yang tergolong dalam fungsi ini adalah spesies C. minutus jantan, $C$. sphinx jantan, $C$. sphinx betina, C. titthaecheilus,jantan, $C$. titthaecheilus, betina, dan $M$. sobrinus betina. Tumbuhan penciri sebagai penyerbuk dan penyebar biji adalah spesies tumbuhan [Acanthaceae] sp.1, Acasia sp., Alnus sp., Baringtonia sp., Bauhi-nia sp., Begoniaceae sp. 1, Betula sp., [Betulaceae] sp. 1, Ceiba pentandra, Ceiba sp. 1, Ceiba sp.2, Ceiba sp.3, [Celastraceae] sp.1, [Compositae] sp.1, [Convolvulaceae] sp.1, Crateva sp., Croton sp., Cyathea sp., [Cyperaceae] sp.2, Cyperus sp., Dacrydium sp., [Dilleniaceae] sp. 1, Durio sp., Durio zibethinus, [Ericaceae] sp.1, [Euphorbia-ceae] sp.1, Hisbiscus sp., Licania sp., Mimosa sp.,
[Orchidaceae] sp.2, [Orchidaceae] sp.4, [Pinaceae] sp. 1, [Pinaceae] sp.2, [Poaceae] sp. 2, Salacia sp., [Typhaceae] sp. 1

Dalam satu spesies kelelawar antara jantan dan betina berbeda dalam mencari sumber pakan, hanya spesies $C$. titthaecheilus,yang memiliki kesamaan karakter dalam pencarian sumber pakan. Kondisi ini menyerupai hasil penelitian Maryati dkk (2008) Sebab perbedaan tersebut belum bisa dijelaskan s mengapa dalam satu jenis berbeda dalam pencarian pakan.

\section{KESIMPULAN}

Fungsi kelelawar dalam ekologi dapat dijelaskan pada penggolongan secara multivariate. Peran kelelawar terbagi menjadi 3 yaitu peran kelelawar sebagai penyerbuk, kelelawar sebagai penyebar biji, kelelawar sebagai penyerbuk dan penyebar biji. Peran kelelawar tersebut berbeda menurut kesukaan terhadap bentuk mahkota bunga, tipe dan ukuran polen.

\section{UCAPAN TERIMAKASIH}

Penulis mengucapkan terioma kasih kepada segenap staf Kebun Raya Bogor yang telah membantu dalam penelitian ini

\section{DAFTAR PUSTAKA}

Dumont, ER., GD Weiblen \& JR Winkelmann. 2004. Prefe-rences of fig wasps and fruit bats for figs of functionally dioecious Ficus pungens. J.Trop. Eco. 20:233-238 
Erdtman, G. 1943. An Introduction to Pollen Analysis. New York: Chronica Botanica.

Erdtman, G. 1952. Pollen Morphology and Plant Taxonomy Angiosperms: An introduction to the study pollen grains and spores. Copenhagen: Munksgard.

Leps, J \& P. Smilauer. 1999. Multivariate Analysis of Ecological Data. Faculty of Biological Sciences, Univer-sity of South Bohemia. Ceske Budejovice.

Maryati, AP. Kartono \& I. Maryanto 2008. Kelelawar Pemakan Buah Sebagai Polinator yang diidentifikasi Melalui Polen yang Digunakan Sebagai sumber Pakannya di Kawasan Sektor Linggarjati, Taman Nasional Ciremai Jawa Barat. J. Biol.Indo. 4 (5): 335347

Marshall, AG. 1985. Old world phytophagous bats (Megachi-roptera) and their food plants:a survey. J.Biol. Lin.Soc.55(1):321-330.

Nayar TS. 1999. Pollen Flora of Maharashtra State India. International Bioscence Series Volume XIV. New Delhi: Today \& Tomorrow's..

Paldat. 2005. Illustrated Handbook on Pollen Terminology. Dept. of Palynology.

Pierson ED. \& WE. Rainey. 1992. The biology of flying foxes of the genus Pteropus: A review. In: DE Wilson and GL Graham (Eds). Pacific island flying foxes proceedings of an international conservation conference. US Fish Wild Serv Biol Rep. p:1-17.

Suyanto A. 2001. Kelelawar di Indonesia. Pusat Penelitian dan Pengembangan Biologi-LIPI. Bogor.

SyahidA. 2009. Transformasi Data. http:/ /abdulsyahid-forum. blogspot.com/ 2009/04/ transformasi-data.html. [20 Juni 2009]

Subarna A. 2006. Sekilas Kebun Raya Bogor. Pusat Konservasi Tumbuhan Kebun Raya Bogor.

Ter Braak, CJF. \& P Smilauer. 1998. Canoco Reference Manual and User's Guide to Canoco for Windows. Ithaca: Microcomputer Power

Tjitrosoepomo, G. 2007. Morfologi Tumbuhan. Yogyakarta: Gadjah Mada Univ Pr

Wiles, GJ. \& MS. Fujita. 1992. Food plants and economic importance of flying foxes on Pacific islands. In: DE Wilson and GL Graham (Eds). Pacific island flying foxes: Proceedings of an international conservation conference 36-38. Yulianto, E. 1992. Preparasi dan dasar determinasi palinologi. Laporan studi praktek Jurusan Teknik Geologi Fakultas Teknologi Mineral ITB. Bandung.

Memasukkan: Juni 2009

Diterima: Februari 2010 